\title{
DEPELOVMENT OF A COMPANION ANDRAGOGICAL COMPETENCY ASSESSMENT INSTRUMENT
}

\author{
Daddy Darmawan ${ }^{1}$, Adi Irvansyah ${ }^{2}$, Rahmat $\operatorname{Syah}^{3}$ \\ ${ }^{1,2}$ Universitas Negeri Jakarta, Indonesia \\ ${ }^{3}$ Institut Bisnis dan Multimedia Asmi, Indonesia \\ Idaddydarmawan@unj.ac.id, ${ }^{2}$ adiirvansyah@unj.ac.id, ${ }^{3}$ rahmat29syah@gmail.com
}

\begin{abstract}
This study aims to develop an andragogical competency assessment instrument. The research method used is a development method that produces a product in the form of a companion andragogical competency assessment instrument. The development of the instrument through some stages, namely the first phase of the instruments, the second phase of judgment instrument by experts, the third phase testing instruments and the fourth analysis item. A sample of respondents taken by using purposive sampling as many as 200 assisted residents in DKI Jakarta. Data Analysis research using the descriptive confirmatory statistical descriptive analysis of factors to find the validity and the formation of factor characteristics and reliability is determined by Alpha Cronbach more than 0,70. The assessment instrument has been declared valid and reliable. The first stage of this development is to compile an instrument based on theoretical studies and obtain 5 dimensions of standard andragogical competence on the principles and 5 dimensions of the mentoring process. The second stage was carried out by the expert justment of the instrument by providing an assessment and revising the grid and instrument items. The content validity was tested by experts and a good aiken statistical index. The third stage is testing in the field and the fourth stage is conducting factor analysis with the results of the value of the construct validity carried out by exploratory and confirmatory factor analysis where the Confirmatory Factor Analysis test results show 34 valid and reliable items.
\end{abstract}

Keywords: assessment, companion, competence, andragogy

\section{PENGEMBANGAN INSTRUMEN PENILAIAN KOMPETENSI ANDRAGOGI PENDAMPING}

\begin{abstract}
ABSTRAK
Penelitian ini bertujuan untuk mengembangkan instrumen penilaian kompetensi andragogi. Metode penelitian yang digunakan adalah metode pengembangan yang menghasilkan produk berupa instrumen penilaian kompetensi andragogi pendamping. Pengembangan instrumen melalui beberapa tahap, yaitu tahap pertama pembuatan instrumen, tahap kedua penilaian instrumen oleh ahli, tahap ketiga pengujian instrumen dan tahap keempat analisis item. Sampel responden diambil dengan menggunakan purposive sampling sebanyak 200 warga binaan di DKI Jakarta. Analisis data penelitian menggunakan analisis deskriptif statistik konfirmatori faktor untuk mencari validitas dan pembentukan karakteristik faktor dan reliabilitas ditentukan oleh Alpha Cronbach lebih dari 0.70. Instrumen penilaian telah dinyatakan valid dan reliabel. Tahap pertama pengembangan ini adalah menyusun instrumen berdasarkan kajian teoritis dan memperoleh 5 dimensi kompetensi andragogi standar pada prinsip dan 5 dimensi pada proses pendampingan. Tahap kedua dilakukan uji ahli instrumen dengan memberikan penilaian dan merevisi kisi dan item instrumen. Validitas isi diuji oleh para ahli dan indeks statistic aiken yang baik. Tahap ketiga adalah pengujian di lapangan dan tahap keempat melakukan analisis faktor dengan hasil nilai validitas konstruk dilakukan dengan analisis faktor eksplorasi dan konfirmatori dimana hasil pengujian Confirmatory Factor Analysis menunjukkan 34 item yang valid dan reliabel.
\end{abstract}

Kata Kunci: penilaian, pendamping, kompetensi, andragogi

\begin{tabular}{|c|c|c|}
\hline Submitted & Accepted & Published \\
\hline 18 Agustus 2020 & 13 September 2020 & 28 September 2020 \\
\hline
\end{tabular}

\begin{tabular}{|l|c|cccc|}
\hline Citation & $:$ & Darmawan, D., Irvansyah, A., \& Syah, R. (2020). Depelovment Of A Companion Andragogical Competency Assessment \\
& & Instrument. Jurnal PAJAR (Pendidikan dan Pengajaran), & $4(5)$, & $1021-1032$. & DOI $\quad:$ \\
http://dx.doi.org/10.33578/pjr.v4i5.8101.
\end{tabular}

\section{PENDAHULUAN}

Kegiatan pendamping merupakan proses memfasilitasi dan mempercepat pencapaian tujuan program khususnya pendidikan di masyarakat

(Montgomery, 2017). Pendamping telah digunakan secara luas di seluruh dunia sebagai salah satu perkembangan utama yang 
berkontribusi pada pengembangan keterampilan, dukungan psikososial atau sosial, dan kemajuan karier serta keberhasilan program sosial (Omoto \& Packard, 2016). Sehingga kegiatan pendamping menjadi faktor penting dalam mempercepat pembangunan suatu negara.

Dengan demikian, pendampingan yang efektif dapat berkontribusi pada peningkatan kesejahteraan dan efektivitas serta peningkatan dan perluasan keterampilan dan kompetensi yang dapat mendukung kemajuan individu, termasuk dalam ranah pendidikan dan karir. (Jacobi, 2008). Sahabat sebagai pekerja sosial harus bertindak dengan integritas dengan berbagai kompetensi. Kompetensi pendamping seseorang adalah mampu beradaptasi secara individu dan sosial dengan memisahkan batas antara kehidupan pribadi dan kehidupan profesional, dan tidak menyalahgunakan posisinya untuk keuntungan pribadi. (Clapton, 2013). Kompetensi pendamping perlu dikembangkan untuk meningkatkan kinerja pendampingan.

Indonesia sebagai negara berkembang memiliki kegiatan pendampingan masyarakat untuk mengatasi masalah pendidikan, sosial dan ekonomi. Salah satu program pemerintah yang membutuhkan bantuan adalah Program Keluarga Harapan (PKH). PKH adalah program pengentasan kemiskinan dan pengembangan sistem perundingan sosial bersyarat bagi masyarakat yang kurang mampu secara ekonomi sebagai program pemberian bantuan tunai bersyarat kepada Rumah Tangga Sangat Miskin (RTSM) yang telah ditetapkan sebagai peserta PKH.

Peserta PKH adalah masyarakat yang termasuk dalam 14 kriteria yang ditetapkan oleh Badan Pusat Statistik (BPS) dan memiliki tanggungan ibu hamil, balita, dan tanggungan anak sekolah sampai jenjang Sekolah Menengah Pertama (SLTP / setara) dalam satu rumah tangga. Program ini telah dilaksanakan di Indonesia sejak tahun 2007 di bawah naungan Kementerian Sosial dan mengalami pemekaran secara bertahap di beberapa daerah di Indonesia. Program ini memiliki hubungan kerjasama dengan sektor lain, seperti: Kementerian Kesehatan, Kementerian
Agama, Kementerian Pendidikan Nasional, BPS, dan PT Pos Indonesia.(Direktorat Jaminan Sosial Kementerian Sosial RI, 2012).

Pendamping PKH adalah sumber daya manusia yang direkrut secara khusus untuk melaksanakan pendampingan di tingkat lapangan. Berdasarkan buku kerja pendamping $\mathrm{PKH}$, tugas pokoknya adalah penyusunan program sosialisasi program PKH di tingkat kecamatan untuk mengadakan pertemuan pendahuluan dengan calon peserta $\mathrm{PKH}$ dan tugas rutin pemutakhiran data, fasilitasi dan penyelesaian kasus pengaduan, berkoordinasi dengan tenaga profesional. melaksanakan kegiatan pendidikan, penyuluhan kesehatan dan mengadakan pertemuan bulanan dengan peserta PKH (Habibullah \& Noviana, 2013).

Selain itu, tugas pendamping PKH lainnya adalah memberikan motivasi kepada peserta PKH untuk melaksanakan komitmennya dalam mengikuti program. Pendamping $\mathrm{PKH}$ juga berupaya mensinergikan pendamping $\mathrm{PKH}$ dalam memberikan pelayanan (Habibullah \& Noviana, 2013). Banyaknya tugas pokok dan fungsi pendamping $\mathrm{PKH}$ yang berkaitan dengan masyarakat membuat profesi pendamping dituntut memiliki kemampuan untuk berhadapan dengan masyarakat.

Salah satu kompetensi yang harus dimiliki oleh fasilitator adalah kompetensi andragogi. Kompetensi andragogi merupakan suatu pendekatan kemampuan yang dapat membantu seorang pendamping mengelola kebutuhan masyarakat berdasarkan pengalaman hidup, sehingga mendorong pengetahuan masyarakat untuk mengembangkan kemampuan pribadinya. (McCauley, Hammer, \& Hinojosa, 2017).

Pengembangan kompetensi dan kemampuan pendidikan orang dewasa dikenal dengan istilah Andragogi (Klapan, Kušić, \& Rogić, 2012). Kerangka andragogis memandu pemilihan, penyampaian, dan pembuatan perangkat instruksional dalam kepemimpinan yang dapat diserap dengan baik oleh komunitas dewasa yang berada dalam masa pemberdayaan (McCauley et al., 2017). Kompetensi dapat mencakup pengulangan fakta dan konsep, 
keterampilan motorik tingkat lanjut, hingga perilaku pembelajaran dan nilai-nilai profesional. Proses andragogi mengandung tujuh unsur pertanyaan yang harus dijawab oleh pendidik (Yatimah, et al., 2020).

Dalam mendukung kompetensi pendamping $\mathrm{PKH}$, analisis kompetensi andragogi penting untuk dikembangkan. Andragogi pada dasarnya adalah tentang pembentukan budi pekerti dan pengetahuan diri serta meliputi pendidikan umum dalam mendampingi masyarakat. Pendamping yang komprehensif dapat memenuhi tujuan dan kebutuhan pendampingan (Anderson, Silet, \& Fleming, 2012). Ciri-ciri kompetensi andragogi yang harus memiliki pendamping adalah sebagai berikut: 1) Self-direction, 2) Adult Learner Experience, 3) Readiness to Learn 4) Praktis dan berorientasi pada hasil, 5) Motivasi Belajar (Knowles, 2003).

Berdasarkan landasan tersebut maka penelitian ini bertujuan untuk mengembangkan instrumen penilaian kompetensi Andragogi fasilitator PKH. Dengan demikian tujuan dari penelitian ini adalah untuk mengetahui gambaran kompetensi andragogi pendamping $\mathrm{PKH}$ dan ingin mengembangkan kompetensi pendamping $\mathrm{PKH}$, sehingga hasil pengembangan kompetensi tersebut dapat digunakan untuk meningkatkan profesionalisme pendamping PKH kedepannya.

\section{KAJIAN TEORETIS}

Kompetensi andragogi dibutuhkan untuk para pendamping dalam melakukan pembinaan terhadap warga dampingan. Kompetensi andragogy telah menjadi kajian dalam penelitian yang berjudul Competency of Adult Learners in Learning: Application of the Iceberg Competency Model oleh Salleh, Khalid, Sulaiman, Mohamad, \& Sern, (2015) menjelaskan bahwa dalam menganalisis bagaimana gambaran kompetensi andragogi para pembelajar dalam system pembelajaran berbasis orangdewasa dengan model iceberg. Sehingga dalam penelitian ini ingin menggali kompetensi andragogi pendamping.

\section{Pengembangan Instrumen Kompetensi}

Pengembangan instrumen untuk membangun kompetensi merupakan bagian dari pengembangan skill bagi pekerja dalam pengaturan pekerjaannya. Sesuai dengan penelitian yang berjudul Programmatic assessment of competency-based workplace learning: When theory meets practice (Bok et al., 2016) menjelaskan bagaimana pengembangan alat ukur untuk kompetensi pembelajaran di tempat kerja berbasis teori yang diaplikasikan dalam praktik.

\section{Pendamping Program Keluarga Harapan}

Program keluarga harapan (PKH) dipengaruhi oleh faktor saluran komunikasi agen perubahan pendamping program keluarga harapan (PPKH) serta faktor perantara internal Rumah Tangga Sangat Miskin (RTSM), (5) Secara simultan, aspek-aspek kredibilitas agen perubahan pendamping Program Keluarga Harapan, efektivitas pesan agen perubahan pendamping Program Keluarga Harapan, kondisi penerima pesan agen perubahan pendamping program keluarga harapan (PPKH), serta faktor saluran komunikasi agen perubahan pendamping program keluarga harapan $(\mathrm{PPKH})$ berpengaruh terhadap faktor perantara internal Rumah Tangga Sangat Miskin (RTSM) dan implikasinya terhadap perubahan sikap Rumah Tangga Sangat Miskin (RTSM)(Suryana, Sugiana, \& Trulline, 2019)

\section{Kompetensi Andragogi}

Kompetensi andragogi diambil berdasarkan penelitian dari Rahardjo \& Suminar dengan desain penelitian tindakan praktis (practical action research). Populasi penelitian adalah tutor pendidikan kesetaraan kejar Paket A, Paket B dan Paket C di Kota Semarang yang masih aktif. Hasil penelitian menunjukkan mayoritas tutor telah dapat menerapkan acuan pedagogi dan andragogi pada tahap perencanaan, pelaksanaan dan evaluasi pembelajaran dengan baik. Penerapan acuan kompetensi amdragogi dalam pengelolaan pembelajaran efektif dapat meningkatkan hasil belajar peserta didik (Joko Rahardjo \& Suminar, 2015). 


\section{METODE PENELITIAN}

Berdasarkan latar belakang, penelitian ini merupakan model pengembangan instrumen penelitian kuantitatif yang merujuk kepada model pengembangan tes menurut Saifuddin Azwar (2012) yang terdiri dari empat tahap pertama tahap pengembangan instrumen dengan identifikasi tujuan pengukuran dan perumusan item indikator, tahap kedua pengujian rasional atau expert judgement tahap ketiga pengujian atau pengujian responden, tahap keempat analisis validasi item dan reliabilitas (Azwar, 2012a).

Teknik pengambilan sampel menggunakan purposive sampling yaitu 200 orang binaan PKH yang tersebar di Provinsi DKI Jakarta untuk menilai kompetensi pendamping. Analisis data penelitian menggunakan statistik deskriptif untuk mendeskripsikan kompetensi dan analisis faktor untuk memperdalam dimensi kompetensi penilaian kompetensi andragogi.

Rumus analisis data yang digunakan meliputi; Aiken's V digunakan untuk membuktikan validitas konten atau penilaian ahli atau membuktikan validitas konten.

$$
\begin{aligned}
& \mathrm{S}=\mathrm{r}-\mathrm{lo} \\
& \mathrm{Lo}= \text { angka penilaian validitas yang terendah } \\
&\text { (misalnya } 1) \\
& \mathrm{C}= \begin{array}{l}
\text { angka penilaian validitas tertinggi } \\
\text { (misalnya } 5)
\end{array} \\
& \mathrm{R}= \text { angka yang diberikan oleh penilai }
\end{aligned}
$$$$
V=\frac{\sum s}{[n(c-1)]}
$$

Exploratory Factor Analysis (EFA) digunakan untuk mengetahui eigenvalue yang dibentuk menjadi faktor atau dimensi variabel laten. (Azwar, 2012b) Alpha Cronbach untuk membuktikan reliabilitas instrumen. Analisis Faktor Konfirmatori Orde Kedua digunakan untuk menguji kesesuaian model. Selanjutnya setelah dilakukan validitas dan reliabilitas akan dibentuk item-item instrumen yang dapat digunakan untuk mengukur kompetensi andragogi.

\section{HASIL DAN PEMBAHASAN}

Tahap awal pengembangan instrumen dengan mengidentifikasi tujuan pengukuran dan perumusan item indikator dilakukan dengan studi teori operasional. Kompetensi andragogi terdiri dari 2 variabel observasi yaitu penilaian pertama kompetensi dasar andragogi dan kedua kompetensi proses pendampingan andragogi dasar. Konstruksi instrumen awal dibahas berdasarkan temuan penelitian sebelumnya dan kajian teoritis yang telah dikembangkan sebelumnya.

Knowles (1980) membuat 4 asumsi tentang karakteristik andragogi dan Knowles ditambah asumsi ke-5 setelah itu (Kearsley \& Knowles, 2010). Ciri-cirinya adalah sebagai berikut; yang pertama adalah "konsep diri", ketika seseorang menjadi dewasa, konsep dirinya berpindah dari satu ke kepribadian yang bergantung pada seseorang menjadi manusia yang mandiri. Yang kedua adalah "pengalaman pelajar dewasa", yaitu ketika seseorang dewasa, dia mengumpulkan pengalaman yang terus meningkat yang merupakan sumber pembelajaran yang terus meningkat. Ketiga, "Kesiapan untuk Belajar" seiring dengan kematangan seseorang untuk belajar semakin berorientasi pada tugas-tugas perkembangan peran sosialnya. Keempat, "orientasi untuk belajar" yaitu ketika seseorang menjadi dewasa, perspektif waktunya berubah dari salah satu aplikasi ilmu yang ditangguhkan menjadi aplikasi yang cepat. Akibatnya, orientasi pembelajaran bergeser dari berpusat pada subjek menjadi berpusat pada masalah. Kelima adalah "motivasi belajar" ketika seseorang sudah dewasa, motivasi belajar bersifat internal. Diperoleh indikator kompetensi dasar andragogi sebagai berikut: 


\section{Tabel 1. Kompetensi Pendamping Prinsip Andragogi Dasar}

\begin{tabular}{|c|c|}
\hline \multirow{2}{*}{$\begin{array}{l}\text { Dimensi } \\
\text { Pengarahan diri sendiri }\end{array}$} & Indikator \\
\hline & $\begin{array}{l}\text { - } \text { Pribadi yang mandiri } \\
\text { - Mampu memimpin } \\
\text { - Mampu berkomunikasi dengan warga belajar } \\
\text { - Memiliki inisiatif }\end{array}$ \\
\hline $\begin{array}{l}\text { Pengalaman } \\
\text { Dewasa }\end{array}$ & $\begin{array}{l}\text { - Memanfaatkan kemampuan warga binaan untuk belajar } \\
\text { - Memanfaatkan tema untuk pembuatan program belajar } \\
\text { - Dapat menggali pengalaman warga belajar } \\
\text { - Dapat memberikan kesempatan warga belajar untuk berdialog }\end{array}$ \\
\hline Kesiapan untuk Belajar & $\begin{array}{l}\text { - Menjelaskan tujuan dan pencapaian sebelum melakukan } \\
\text { pendampingan } \\
\text { - } \quad \text { Beri penjelasan } \\
\text { - }\end{array}$ \\
\hline $\begin{array}{l}\text { Praktis dan berorientasi } \\
\text { pada hasil }\end{array}$ & $\begin{array}{l}\text { - } \quad \text { Memiliki target atau pencapaian yang jelas } \\
\text { - } \quad \text { Berorientasi pada laba atau hasil } \\
\text { - } \quad \text { Kegiatan pendampingan memiliki tugas }\end{array}$ \\
\hline Motivasi belajar & $\begin{array}{ll}\text { - } & \text { Gigih dan ulet } \\
\text { - } & \text { Optimis } \\
\text { - } & \text { Memiliki tekad, kerja keras }\end{array}$ \\
\hline
\end{tabular}

Hasil pencarian terdapat 5 dimensi kompetensi dasar andragogi. Pengarahan diri sendiri yang menunjukkan orang dewasa dalam memberikan bantuan. Pengalaman Pelajar Dewasa adalah dalam bentuk pengalaman pendamping dan orang-orang yang diberi bantuan di sana diberikan berbagi dan memberi. Kesiapan Belajar berupa tujuan dalam pembelajaran sehingga peserta perlu mengetahui bagaimana tujuan yang mereka pelajari. Praktis dan berorientasi pada hasil, begitulah pendamping melakukan pendampingan. Motivation to Learn adalah bagaimana seorang pendamping memiliki sikap dan motivasi belajar serta memberikan bantuan dengan penuh semangat. Kelima dimensi tersebut diadaptasi dari kajian teoritis berdasarkan apa yang dikemukakan oleh Kessels (2014).

Tabel 2. Kompetensi proses pendamping andragogi

\begin{tabular}{ll}
\hline Dimensi & Indikator \\
\hline Mempersiapkan pelajar & - Menyediakan informasi, \\
& - Mempersiapkan target orang untuk berpartisipasi, \\
& denganfatkan lingkungan binaan, dimulai \\
& - Doing together planning \\
& - Melakukan perencanaan bersama \\
Membangun suasana & - informal, \\
Bimbingan & membangun kepercayaan, tanggung jawab, \\
Menganalisis kebutuhan & - Menilai
\end{tabular}


Kegiatan Pendampingan

Evaluasi
- Saling bernegosiasi

- Membuat proyek kerja

- Investigasi Proyek, studi independen,

- Berbagi atau memanfaatkan pengalaman dalam memecahkan masalah secara kolaboratif (kerja tim)

- Saling menilai dan memvalidasi oleh rekan-rekan

- Mengevaluasi / meminta pendapat dengan fasilitator, ahli di luar pendampingan

- Memperbaiki sistem pendampingan yang mengacu pada kriteria
Hasil penelusuran menunjukkan bahwa terdapat 6 dimensi kompetensi dalam proses pendampingan andragogi: mempersiapkan peserta didik, membangun suasana, bimbingan, menganalisis kebutuhan, kegiatan pendampingan, dan evaluasi. Selanjutnya dicari validitas isi atau pada penelitian tahap kedua ini dilakukan teknik indeks Aiken $\mathrm{V}$ berdasarkan expert judgement terhadap item-item dalam hal sejauh mana itemitem tersebut mewakili konstruk yang diukur. Penilaian dilakukan dengan memberikan skor 1-4 (Azwar, 2012b).

Validitas isi mencerminkan representasi dan relevansi sekumpulan item yang digunakan untuk mengukur suatu konsep yang dilakukan melalui analisis rasional terhadap isi tes melalui penilaian panel ahli. Validitas ini mengacu pada keakuratan pengukuran berdasarkan isi instrumen untuk memastikan bahwa item skala yang digunakan telah memenuhi konsep keseluruhan isi atau kesesuaian item tersebut. (Crocker, 2015). Bukti validitas isi instrumen lembar penilaian dinilai oleh tiga orang ahli. Kemudian hasil tersebut digunakan untuk menghitung besarnya koefisien validitas isi dari Aiken's V. Besarnya koefisien validitas dapat diterima jika loading factor $\geq 0.70$.

Tabel 3. Indeks Kompetensi Pendamping Andragogi Dasar Aiken V

\begin{tabular}{ccc}
\hline Item & Aiken V & Results \\
\hline Item_1 & 0.8 & Valid \\
Item_2 & 0.7 & Valid \\
Item_3 & 0.85 & Valid \\
Item_4 & 0.9 & Valid \\
Item_5 & 0.81 & Valid \\
Item_6 & 0.77 & Valid \\
Item_7 & 0.84 & Valid \\
Item_8 & 0.85 & Valid \\
Item_9 & 0.91 & Valid \\
Item_10 & 0.81 & Valid \\
Item_11 & 0.98 & Valid \\
Item_12 & 0.85 & Valid \\
Item_13 & 0.92 & Valid \\
Item_14 & 0.75 & Valid \\
Item_15 & 0.97 & Valid \\
Item_16 & 0.96 & Valid \\
Item_17 & 0.86 & Valid \\
\hline
\end{tabular}


Berdasarkan Tabel 3 terlihat bahwa instrumen penilaian kompetensi andragogi memiliki koefisien validitas isi Aiken's $\mathrm{V}$ yang tinggi $\geq 0.7$ dari 5 dimensi yang berjumlah 17 item. Ada beberapa item yang dikoreksi oleh ahli antara lain item 10.11 dan item 17. Item 10 menjelaskan tentang pendamping dapat memberikan penjelasan atau alternatif yang diperlukan. Pada butir 11 fasilitator memahami masalah yang dibutuhkan peserta, pada butir 17 pendamping memiliki tekad, kerja keras.

Tabel 4. Indeks kompetensi proses pendampingan Andragogi Aiken V

\begin{tabular}{ccc}
\hline Item & Aiken V & Results \\
\hline Item_18 & 0.87 & Valid \\
Item_19 & 0.92 & Valid \\
Item_20 & 0.79 & Valid \\
Item_21 & 0.91 & Valid \\
Item_22 & 0.95 & Valid \\
Item_23 & 0.81 & Valid \\
Item_24 & 0.92 & Valid \\
Item_25 & 0.87 & Valid \\
Item_26 & 0.85 & Valid \\
Item_27 & 0.8 & Valid \\
Item_28 & 0.84 & Valid \\
Item_29 & 0.82 & Valid \\
Item_30 & 0.89 & Valid \\
Item_31 & 0.87 & Valid \\
Item_32 & 0.76 & Valid \\
Item_33 & 0.92 & Valid \\
Item_34 & 0.84 & Valid \\
\hline
\end{tabular}

Setelah dilakukan penilaian ahli, tahap ketiga yaitu instrumen asesmen digunakan untuk menilai kompetensi pendamping PKH yang akan dibagikan kepada warga binaan yang berjumlah 200 responden. Tahap ketiga melakukan hasil analisis data yang membuktikan validitas dan reliabilitas. Pembuktian keabsahan ekstrak dilakukan dengan uji analisis faktor eksplorasi dan konfirmatori.

Analisis data statistik dilakukan dengan metode Structural Equation Modeling (SEM) atau yang dikenal dengan Pemodelan Persamaan Struktural. Metode SEM dibagi menjadi dua bagian yaitu; 1) Confirmatory Factor Analysis
(CFA) untuk menguji validitas dan reliabilitas model pengukuran. Apabila dari hasil pengujian dengan CFA ditemukan bahwa model pengukuran valid dan reliabel (melalui fit index), hal ini menunjukkan bahwa instrumen penelitian yang digunakan valid dan reliabel, dan 2) Menguji model penelitian dan hipotesis.The Goodness of Fit Test pada prinsipnya bertujuan untuk mengetahui apakah suatu sebaran data dari suatu sampel mengikuti sebaran teoritis tertentu atau tidak. Pada tabel 5 dijelaskan Goodness of Fit Basic Kompetensi Pendamping Andragogi. Dan Pada tabel 6 dijelaskan proses pendampingan Goodness of Fit Andragogy. 
Tabel 5. Goodness of Fit Basic Andragogy Companion Competencies

\begin{tabular}{ccc}
\hline Index & Estimation & Results \\
\hline$\chi^{2}$ Chi- Square & 126.61 & FIT \\
P & 0.12 & FIT \\
RMSEA & 0.046 & FIT \\
GFI & 0.93 & FIT \\
AGFI & 0.90 & FIT \\
DF & 109 & FIT \\
CFI & 0.96 & FIT \\
\hline
\end{tabular}

Pada penelitian ini diperoleh nilai Chisquare sebesar 126.61 dengan $\mathrm{p}=0.12$ (lebih besar dari 0.05). Berdasarkan hasil pengujian diperoleh nilai RMSEA sebesar 0.046. Goodness of Fit Index (GFI) dalam penelitian ini adalah 0.93 atau mendekati 1. Sedangkan nilai AGFI adalah 0.90 (hampir mendekati 0.95). Sedangkan nilai DF sebesar 109. Terakhir berdasarkan hasil pengujian diketahui bahwa indeks CFI sebesar 0.96.

Tabel 6. Goodness of Fit Kompetensi proses pendamping andragogi

\begin{tabular}{ccc}
\hline Index & Estimation & Results \\
\hline$\chi 2$ Chi- Square & 137.50 & FIT \\
P & 0.14 & FIT \\
RMSEA & 0.031 & FIT \\
GFI & 0.92 & FIT \\
AGFI & 0.94 & FIT \\
DF & 109 & FIT \\
CFI & 0.95 & FIT \\
\hline
\end{tabular}

Pada tabel 6 diperoleh nilai Chi-square sebesar 137.50 dengan $\mathrm{p}=0.14$ (lebih besar dari $0,05)$. Berdasarkan hasil pengujian diperoleh nilai RMSEA sebesar 0.031. Goodness of Fit Index (GFI) dalam penelitian ini adalah 0.92 atau mendekati 1. Sedangkan nilai AGFI adalah 0.94 (hampir mendekati 0.95). Sedangkan nilai DF sebesar 109. Terakhir berdasarkan hasil pengujian diketahui bahwa indeks CFI sebesar 0.95.

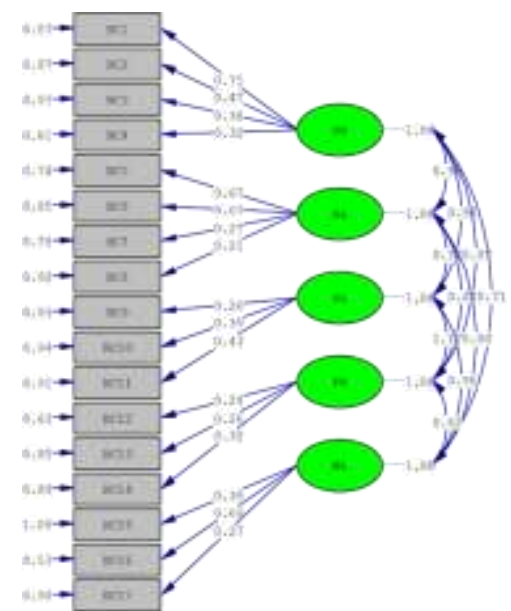

Gambar 1. Basic Andragogy Companion Competencies Constructs 
Gambar 1 menunjukkan model pengukuran CFA yang memiliki 5 konstruksi dengan 17 dimensi manifes untuk Kompetensi Pendamping Andragogi Dasar. Nilai faktor pemuatan berada di tengah garis langsung menuju variabel manifes. Sedangkan skor yang berada di belakang variabel manifes merupakan standar error dari setiap variabel manifes.

Model struktural mencirikan hubungan antara konstruk atau variabel laten dan mendefinisikan variabel laten yang secara tidak langsung atau langsung menyebabkan perubahan nilai variabel laten lainnya dalam model (Byrne, 2013). Satu set CFA dikembangkan sebagai bagian dari analisis. Penilaian Kemampuan Awal yang disajikan sebelumnya (lihat Gambar 1) adalah jalur awal dari model struktur teoritis. Hasil CFA menunjukkan bahwa $\chi 2$ dari 124.15 dengan $109 \mathrm{df}$ signifikan secara statistik dengan $\mathrm{p}<0.05$, yang menyarankan kecocokan yang tidak pantas. Byrne (2013) mencatat bahwa $\chi 2$ sangat sensitif terhadap ukuran sampel dan sering merekomendasikan kecocokan yang buruk dengan ukuran sampel yang besar. Statistik kecocokan yang tersisa mengungkapkan kecocokan sedang antara model teoritis dan data dengan sedikit lebih rendah dari skor yang diterima umum $0.50(\chi 2 /$ df $=1.13$. Gambar 1 menunjukkan bahwa ada hubungan antara 5 dimensi. Dilihat dari nilai-p 0.152 atau lebih besar dari 0.05 .

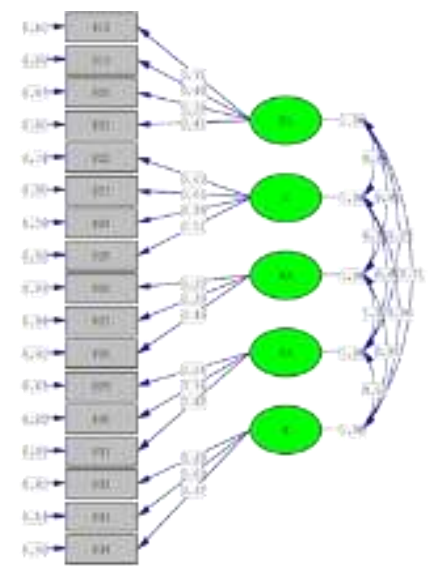

Gambar 2. Process Andragogy

Gambar 2 menunjukkan model pengukuran CFA yang memiliki 5 konstruksi dengan 17 dimensi manifes untuk Kompetensi Pendamping Andragogi Dasar. Nilai faktor pemuatan berada di tengah garis langsung menuju variabel manifes. Sedangkan skor yang berada di belakang variabel manifes merupakan standar error dari setiap variabel manifes.

Model struktural mencirikan hubungan antara konstruk atau variabel laten dan mendefinisikan variabel laten yang secara tidak langsung atau langsung menyebabkan perubahan nilai variabel laten lainnya dalam model. (Byrne, 2013). Satu set CFA dikembangkan sebagai bagian dari analisis. Penilaian Kemampuan Awal yang disajikan sebelumnya (lihat Gambar 1) adalah jalur awal dari model struktur teoritis. Hasil dari CFA menunjukkan bahwa 2 dari 133.17 dengan 109 df secara statistik signifikan dengan $\mathrm{p}<0.05$, yang menunjukkan kecocokan yang tidak sesuai. Byrne (2013) mencatat bahwa $\chi 2$ sangat sensitif terhadap ukuran sampel dan sering merekomendasikan kecocokan yang buruk dengan ukuran sampel yang besar. Statistik kecocokan yang tersisa mengungkapkan kecocokan sedang antara model teoritis dan data dengan sedikit lebih rendah dari skor yang diterima umum $0.50(\chi 2 / \mathrm{df}=1.22$. Gambar 1 menunjukkan bahwa ada hubungan antara 5 dimensi. Dilihat dari nilai-p sebesar 0.123 atau lebih besar dari 0.05 . 
Tabel 7. Variance Explained Factors

\begin{tabular}{lccc}
\hline Model & KMO MSA & Eigenvalue & Reliability \\
\hline Basic Andragogy Competencies & 0.94 & 1 Factor & 0.90 \\
Self-direction & 0.83 & 1 Factor & 0.79 \\
Adult Learner Experience & 0.98 & 1 Factor & 0.81 \\
Readiness to Learn & 0.83 & 1 Factor & 0.94 \\
Practical and results-oriented & 0.87 & 1 Factor & 0.97 \\
Motivation to Learn & & & \\
Proses Competencies Base on Andragogy & & 1 Factor & 0.89 \\
Preparing the learner & 0.96 & 1 Factor & 0.85 \\
Membangun suasana & 0.85 & 1 Factor & 0.82 \\
Menganalisis kebutuhan & 0.97 & 1 Factor & 0.89 \\
Aktivitas Pendampingan & 0.90 & 1 Factor & 0.88 \\
Evaluasi & 0.95 &
\end{tabular}

Kesiapan menunjukkan keandalan skala yang meningkat secara signifikan dari 0.79 menjadi 0.97. Nilai reliabilitas yang diinginkan 0.70 maka nilai di bawah ini perlu dibuang (Taber, 2018). Sampel item survei prinsip andragogi yang termasuk dalam setiap skala bersama dengan statistik keandalan skala dijelaskan pada Tabel 7.

Kaiser Meyer Olkin Measure of Sampling (KMO) adalah indeks perbandingan jarak antara koefisien korelasi dan koefisien korelasi parsial. Jika jumlah kuadrat koefisien korelasi parsial di antara semua pasang variabel bernilai kecil dibandingkan dengan jumlah kuadrat koefisien korelasi, maka akan menghasilkan nilai KMO mendekati 1. Nilai KMO dianggap mencukupi jika lebih dari 0.5 (Banu \& Duraipandian, 2014). Hasil penelitian menunjukkan bahwa nilai Kaiser Meyer Olkin Measure MSA lebih besar dari 0.5. Dengan demikian persyaratan KMO memenuhi persyaratan. Nilai eigen pada tabel 7 menjelaskan bahwa setiap dimensi membentuk 1 faktor yang terdiri dari item-item pengukuran. Selanjutnya nilai reliabilitas pada tabel 7 lebih besar dari 0.7 artinya dapat disimpulkan bahwa dimensi reliabel atau konsisten.

Kompetensi andragogi dalam dunia komunitas advokat belum teruji secara memadai, komunitas pendidikan orang dewasa terus mempertanyakan adopsi andragogi tanpa penjelasan yang jelas bagaimana pengaruhnya terhadap pendampingan. Hasil penelitian ini menunjukkan bahwa ada dua perspektif tentang kompetensi andragogi yang perlu diukur. Pertama, pengetahuan dan paradigma andragogi pada petugas pendamping dan kedua adalah pelaksanaan pendampingan itu sendiri. Pendekatan pendampingan orang dewasa telah disarankan bahwa hampir tidak mungkin teori komprehensif tentang pembelajaran orang dewasa muncul dan berlaku untuk semua situasi pembelajaran orang dewasa termasuk pendampingan.

Temuan peneliti menggambarkan bahwa kualitas psikometri yang dikembangkan adalah valid dan reliabel serta mengukur perilaku andragogi instruktur berdasarkan lima prinsip dan lima elemen proses andragogi dalam pendamping. Meskipun hanya lima dari enam prinsip andragogi yang terungkap, dan 17 dimensi proses andragogi yang diteliti dalam penelitian ini, penelitian ini lebih berhasil dari penelitian sebelumnya dalam mengukur konstruksi andragogi (prinsip dan elemen desain proses). Temuan yang disajikan dalam bab ini menggambarkan bahwa sebagian besar konstruksi teoretis secara efektif ditangkap dan diukur dalam instrumen.

Holton et al. (2009) mencatat bahwa prasyarat utama untuk menumbuhkan tubuh pengetahuan di bidang pendidikan orang dewasa 
adalah pengembangan instrumen pengukuran. Salah satu penentu sikap profesional tutor atau pendidik adalah pengalaman tutor dalam evaluasi karena hal ini memungkinkan tutor untuk menginformasikan bagaimana berbagai jenis ulasan digunakan atau disalahgunakan dan apa yang dapat dilakukan untuk meningkatkan praktik penilaian di kelas (D. Darmawan et al. 2020).

\section{SIMPULAN DAN REKOMENDASI}

Kontribusi utama penelitian ini adalah mengisolasi dan mengukur prinsip andragogi dan desain pendamping proses andragogi. Jelas bahwa instrumen ini akan membutuhkan pengembangan lebih lanjut, meskipun ini merupakan kemajuan yang signifikan. Hasil penelitian ini membentuk instrumen penilaian kompetensi pendamping dilihat dari 2 sisi. Pertama adalah kemampuan andragogi kepala sekolah pendamping dan kedua adalah proses pelaksanaan pendampingan. Dari dimensi prinsip andragogi melahirkan 17 indikator dan dari proses penyampaian 17 indikator. Teknik yang lebih baik untuk menangani orang dewasa dapat menjadi alat ukur yang andal untuk menguji andragogi secara empiris dan kemudian memberikan temuan yang signifikan kepada praktisi sehingga kesesuaian dan penerapan andragogi dalam pengaturan pembelajaran mereka dapat dievaluasi.

\section{DAFTAR PUSTAKA}

Anderson, L., Silet, K., \& Fleming, M. (2012). Evaluating and giving feedback to mentors: new evidence-based approaches. Clinical and Translational Science, 5(1), 71-77. https://doi.org/10.1111/j.17528062.2011.00361.x

Azwar, S. (2012a). Penyusunan Skala Psikologi. In Pustaka Pelajar.

Azwar, S. (2012b). Reliabilitas dan validitas edisi 4. Yogyakarta: Pustaka Pelajar.

Banu, A. R., \& Duraipandian, K. (2014). Development of an Instrument To Measure Work Life Balance of It Professionals in Chennai. International Journal of Management.

Bok, H. G. J., Jaarsma, D. A. D. C., Spruijt, A., Van Beukelen, P., Van Der Vleuten, C. P.
M., \& Teunissen, P. W. (2016). Feedbackgiving behaviour in performance evaluations during clinical clerkships. Medical Teacher. https://doi.org/10.3109/0142159X.2015.10 17448

Byrne, B. M. (2013). Structural equation modeling with AMOS: Basic concepts, applications, and programming, second edition. In Structural Equation Modeling with AMOS: Basic Concepts, Applications, and Programming, Second Edition. https://doi.org/10.4324/9780203805534

Clapton, K. (2013). Developing professional boundaries guidance for social workers. Journal of Adult Protection. https://doi.org/10.1108/146682013112999 08

Crocker, L. (2015). Content Validity. In International Encyclopedia of the Social \& Behavioral Sciences: Second Edition. https://doi.org/10.1016/B978-0-08097086-8.44011-0

D. Darmawan; D.Yatimah; K. Sasmita; R. Syah. (2020). Analysis of non-formal education tutor capabilities in exploring assessment for science learning. Jurnal Pendidikan IPA Indonesia, 9(2), 70-78. https://doi.org/10.15294/jpii.v9i2.24025

Direktorat Jaminan Sosial Kementerian Sosial RI. (2012). Pedoman umum program keluarga harapan. Jakarta: Direktorat Jaminan Sosial Kementerian Sosial RI.

Habibullah \& Noviana. (2013). Kebijakan Pendamping Program Keluarga Harapan. Jakarta: P3KS Press.

Holton, E. F., Wilson, L. S., \& Bates, R. A. (2009). Toward development of a generalized instrument to measure andragogy. Human Resource Development Quarterly. https://doi.org/10.1002/hrdq.20014

Jacobi, M. (2008). Mentoring and Undergraduate Academic Success: A Literature Review. Review of Educational Research. https://doi.org/10.3102/003465430610045 05 
Joko Rahardjo, P., \& Suminar, D. (2015). COASTAL COMMUNITY DEVELOPMENT MODEL BASED IN NONFORMAL EDUCATION THROUGH OPTIMALIZATION OF FAMILY EMPOWERMENT POST AS A POVERTY REDUCTION STRATEGY. In International Journal of Education and Research.

Kearsley, G., \& Knowles, M. (2010). Andragogy - the theory into practice database. Retrieved October.

Kessels, J. W. M. (2014). Andragogy. In The Routledge Companion to Human Resource Development. https://doi.org/10.4018/9781-59140-555-9.ch014

Klapan, A., Kušić, S., \& Rogić, D. (2012). Influence of migrations on adult education in Croatia during the croatian war of independence and in the post war period. Andragoska Spoznanja. https://doi.org/http://dx.doi.org/10.4312/as .18.1.38-54

Knowles, M. S. (1980). THE MODERN PRACTICE OF ADULT EDUCATION , From Pedagogy to Andragogy What Is Andragogy? Business.

Knowles, M. S. (2003). ANDRAGOGY Malcolm S. Knowles ASSUMPTIONS. Elements.

M Omoto, A., \& D Packard, C. (2016). The power of connections: Psychological sense of community as a predictor of volunteerism. In The Journal of social psychology (Vol. 156).

https://doi.org/10.1080/00224545.2015.11 05777

McCauley, K. D., Hammer, E., \& Hinojosa, A. S. (2017). An Andragogical Approach to Teaching Leadership. Management Teaching Review. https://doi.org/10.1177/237929811773688 5

Montgomery, B. L. (2017). Mapping a Mentoring Roadmap and Developing a Supportive Network for Strategic Career Advancement. SAGE Open. https://doi.org/10.1177/215824401771028 8
Salleh, K. M., Khalid, N. H., Sulaiman, N. L., Mohamad, M. M., \& Sern, L. C. (2015). Competency of Adult Learners in Learning: Application of the Iceberg Competency Model. Procedia - Social and Behavioral Sciences. https://doi.org/10.1016/j.sbspro.2015.08.1 60

Suryana, A., Sugiana, D., \& Trulline, P. (2019). Pengaruh Atribut Agen Perubahan (Agent of Change) Pendamping Program Keluarga Harapan (PKH) terhadap Perubahan Sikap Rumah Tangga Sangat Miskin (RTSM) peserta Program Keluarga Harapan (PKH) di Kabupaten Bandung. Jurnal Manajemen Komunikasi. https://doi.org/10.24198/jmk.v1i1.10061

Taber, K. S. (2018). The Use of Cronbach's Alpha When Developing and Reporting Research Instruments in Science Education. Research in Science Education. https://doi.org/10.1007/s11165-016-96022

Yatimah, D., Sasmita, K., Darmawan, D., \& Syah, R. (2020). Pengaruh kompetensi andragogi dan komunikasi interpersonal terhadap kemampuan manajerial tutor di Balai Latihan Kerja DKI Jakarta. Jurnal Pendidikan Dan Pemberdayaan Masyarakat (JPPM), 7(1), 68-81. 